\title{
INTERNETHASZNÁLATI SZOKÁSOK FELTÉRKÉPEZÉSE A ROGERS-FÉLE ELMÉLET SZERINT A MAGYARORSZÁGI IDŐSÖDŐK KÖRÉBEN
} MEASURING THE INTERNET USAGE HABITS AMONG THE ELDERLY
IN HUNGARY ACCORDING TO ROGERS' THEORY

A fejlett társadalmakban egyre nagyobb arányt képviselő idős generáció innovációs magatartásának kutatása - az információtechnológia rohamos fejlődését figyelembe véve - üzleti, társadalmi és erkölcsi szempontból nézve sem megkerülhető feladat. Az idős korosztálynál a szükséges tudás és képességek hiánya az online aktivitásnak jellemzően korlátokat szab, ugyanakkor a használati előnyök is egyre inkább kirajzolódnak számukra, sőt, ez a fajta felkészültség akár megkerülhetetlenné válik. Mindez ráirányítja a figyelmet az idősek innovációs magatartásának minél többoldalúbb feltérképezésére. Figyelembe kell venni, hogy az idős korosztály is erősen tagozódik, az egészségi állapot, az életkörülmények, az életstílus, az értékek és más tényezők innovációs elfogadás szempontjából is eltérő magatartásmintákat rajzolnak ki. De különbségek vannak az idősek két generációja, az érettek (veteránok) és a baby boomerek (Ratkó-korszak szülöttei) között is, hiszen más életszakaszban érte el őket az internet berobbanása. Primer kutatásukban a szerzők ennek a két időskori generációnak az információtechnológia használatára vonatkozó magatartását vizsgálják hazai viszonylatban, a Rogers-féle innovációelfogadási modellt elméleti alapul véve.

\section{Kulcsszavak: babyboomerek, generációmarketing, innovációelfogadás, Ratkó-korszak szülöttei, veteránok}

From business, social and moral point of view it is an inevitable task to research the older generation's innovation habits, because they are gaining an increasing share in advanced societies. Of course we have to take into account the rapid development of information technology too. The lack of knowledge and skills required for online activity among the elderly people are typically setting limits, but at the same time, the benefits of usage are becoming more and more evident to them, and even this kind of readiness is becoming more and more inevitable. This draws the attention on the multilateral mapping of the innovation behaviour of the elderly. It's important to pay attention while analysing the elderly people that their group is strongly divided by health status, by living conditions, by lifestyles, by values and other factors, so according to the innovation acceptance they draw different patterns of behaviour. And of course we have to keep in mind that there are also differences between the two generations of the elderly, the veterans and the baby boomers (people born in Ratko-era), because they have been getting to know the Internet in different life stages. In this primary research, the authors study the behaviour of the two older Hungarian generations (veterans and those born in the Ratko-era) through the usage of information technology, based on the theory of Rogers' innovation acceptance model.

Keywords: baby-boomers, generation marketing, innovation acceptance, those born in Ratko-era, veterans

\section{Finanszírozás/Funding:}

A szerzők a tanulmány elkészítésével összefüggésben nem részesültek pályázati vagy intézményi támogatásban. The authors did not receive any grant or institutional support in relation with the preparation of the study.

\section{Szerzők/Authors:}

Dr. Bernschütz Mária, egyetemi adjunktus, Budapesti Műszaki és Gazdaságtudományi Egyetem, (bernschutz@mvt.bme.hu) Danó Györgyi, egyetemi tanársegéd, Budapesti Műszaki és Gazdaságtudományi Egyetem, (dano@mvt.bme.hu) Kovács István, mesteroktató, Budapesti Műszaki és Gazdaságtudományi Egyetem, (kovacs.istvan@mvt.bme.hu) Dr. Petruska Ildikó, egyetemi docens, Budapesti Műszaki és Gazdaságtudományi Egyetem, (petruskai@mvt.bme.hu)

A cikk beérkezett: 2019. 05. 31-én, javítva: 2020. 03. 07-én, elfogadva: 2020. 10. 05-én.

This article was received: 31. 05. 2019, revised: 07. 03. 2020, accepted: 05. 10. 2020. 
A z idősebb korosztály a fejlett országokban a leggyorsabban növekvő demográfiai korcsoport. Csak az Egyesült Államokban az 55 éven felüliek rendelkeznek az ország vagyonának 75 százaléka felett (Linden, 1986 in Kennett et al., 1995; Proctor et al., 2015). Napjainkban a nők szülési hajlandósága (fertilitása) alacsony, alatta marad a reprodukcióhoz szükséges szintnek, a halálozási mutatók viszont javulnak. A fennálló alacsony termékenység, valamint az öregkorban is javuló életesélyek (lásd IT-eszközök használata preventív alkalmazással) következtében nő és a jövőben növekedni fog az idősek aránya. Ráadásul 2015 óta némiképp lassult a nyugdíjreformok üteme a világ fejlettebb országaiban. A sokak által kívánatosnak tartott rugalmas nyugdíjba menetel aránya nemigen nő az OECD-ben sem. Az, hogy tovább élünk, elméletben pozitívan hathat az aktivitásra (Botos, 2018).

Jelenleg már a magyar lakosság 19 százaléka (több mint 1,8 millió ember) 65 év feletti, és 2030-ra ez a szám várhatóan eléri majd a kétmilliót. A „feminizáció” Magyarországon is az idősödés demográfiai jellemzői között szerepel, az idősödő népességben egyre határozottabbá válik a nők többsége.

Az elöregedő társadalmakban fontos lenne üzletileg is jobban megérteni az idősebb fogyasztók igényeit és innovációelfogadási hajlandóságát (Moschis et al., 2004), ahogy erre egy Egyesült Királyságban végzett kutatás is jutott. Ennek ellenére a marketingszakma nem igazán foglalkozik ezzel a korosztállyal, nem szólnak hozzájuk, nincs program feléjük, és nem figyelnek arra sem, hogy megtartsák idősebb fogyasztóikat. Iyer és Eastman (2016) szerint pedig óriási előnyt jelentene a cégeknek, ha felismernék ennek jelentőségét, és akár tradicionális médiumokkal való kommunikáción keresztül ösztönöznék az idősebbeket az internethasználatra.

Ez egyúttal annak a szükségességét is felveti, hogy változzanak az idősek magatartására vonatkozó sztereotípiák. Magyar egyetemi hallgatók körében vizsgálták az idős személyekre vonatkozó sztereotípiákat (Kovács et al., 2018), és arra a következtetésre jutottak, hogy ezek kultúránként eltérhetnek, így hatásuk másképpen érvényesül a világ különböző pontjain.

Törőcsik és Lampek (2016) kutatásában a lakossági mintában megjelenő sztereotípiák szerint idős az, aki nem tudja ellátni magát $(60,6 \%)$, aki szellemileg leépült (50,5\%), akinek megromlott az egészségi állapota (49\%), illetve aki nem tud alkalmazkodni a változásokhoz (35,5\%). Talán ehhez az utolsó sztereotípiához kapcsolóható leginkább az idősek innovációs magatartásának negativ megitélése. Éppen ezért nagyon aktuális és releváns kutatási terület az idősek aktív IT-használatának vizsgálata, az esetleges gátló tényezők feltárása, az ezek csökkentésére, kiküszöbölésére, illetve a használat ösztönzésére vonatkozó megoldások kimunkálása.

Ahhoz, hogy az idősebb generációk számára is hasznos és élvezetes legyen az internetezés, ismernünk kell, mi jellemzi a sikeres internetfelhasználót. Olyan képességekkel, illetve készséggel kell rendelkeznie, amivel a felhalmozódott információt értelmezi tudja: keresési technika, navigálási technika, az adatok szürése. Sajná- latosan ezek az információkezelési jártasságok pont az idősebb generációkból hiányoznak (Cresci et al., 2010). A szakirodalomban tárgyalt, a technológia használattal kapcsolatos további befolyásoló faktorok - amelyek gátolják az idősebb generációt abban, hogy könnyedén fogadják a technológiai újításokat - a következők: a technológiának tulajdonított érték, az észlelt hasznosság, a szükséges pénzügyi ráfordítás mértéke, a technológiai hozzáférés lehetősége, a technikai segítségnyújtás mértéke, a közösségi segítségnyújtás mértéke, érzelmi állapot, az észlelt függetlenség, a múltbéli tapasztalat, valamint a használat magabiztossága (Lee \& Coughlin, 2015).

\section{Elméleti megközelítés}

\section{Innovációk fogyasztói elfogadása}

A mai gazdaságban az innováció jelentősége megkérdőjelezhetetlen. Empirikus kutatások eredményeire hivatkozva Shukla (2009) megállapítja, hogy a gazdasági szervezetek 90 százaléka számára az elsők között említett magas prioritású cél az innovatív képességek javítása. Baporikar (2014) kiemeli, hogy az innovációnak ugyanúgy van életgörbéje, mint az üzleti folyamatoknak, a termékeknek és a megoldásoknak, így az egyes innovatív eredmények csak időlegesen képesek versenyelőnyt biztosítani. Grübler et al. (1999) a technológiai szakértelmet hangsúlyozza, mint a hosszú távon fenntartható termelékenység és gazdasági fejlődés meghatározó elemét. Ez egybecseng a hétköznapi asszociációval, mely az innovációt annak technológiai vonatkozásában értelmezi. Az innováció azonban ennél lényegesen összetettebb fogalom.

Schumpeter (1980, idézi Bőgel, 2008) értelmezése szerint az innováció szorosan összefügg a termeléssel, tehát a vállalkozások magtevékenységével. Azáltal, hogy „a termelés a meglévő dolgok és erők kombinációját jelenti, az innováció tehát újfajta kombinációként értelmezhető" (Bőgel, 2008). Schumpeter (1980) elmélete fontosnak tartja, hogy az újfajta kombináció tipikusan nem a bejáratott folyamatok fejlesztésének eredménye, hanem radikálisan új megközelítésé, ami gyakran a piaci struktúrán kívüli szervezetekből érkezik és a meglévő piaci viszonyok lerontásával jár. Az innovációt ezért Schumpeter (1980) „,teremtő rombolás"-nak nevezi. Az alkotás és a pusztítás kettőssége (és ezáltal a radikális piaci versenyhez kapcsolása) az innováció schumpeteri teóriájának központi eleme. Ezt a képét azonban az újabb elméletek sok tekintetben bírálják.

Baporikar (2014) az innovációt leíró tulajdonságok kategorizálásának érdekében egy sor definíciós kísérletet tesz, amiknek a hiányosságaira rámutatva újabb elemekkel bővíti azt. A definíció kiindulópontja a szó szótári meghatározása: Valami létező dolog megváltoztatása új valami új bevezetésével (The New Oxford Dictionary of English, 1998, idézi Baporikar, 2014).

Az innovatív megoldások tükrében fontos áttekinteni az újdonságok kipróbálását jellemző fogyasztói magatartás jellemzöit, hiszen ezen a ponton a fogyasztó által érzékelt kockázatnak, az ismeretlenségnek és az ezt ellensúlyozó motivációs tényezőknek meghatározó szerep jut 
az új termékek vagy szolgáltatások sorsának alakulásában - még olyan esetekben is, ahol az innováció a fogyasztói igények mentén jelenik meg.

Ezzel foglalkozik a Rogers-féle elmélet (1995), mely az innovációt olyan gyakorlatként határozza meg, amelyet az egyén, a felhasználó újnak értékel. Természetesen minderre kihat az is, hogy milyen jellegzetességeket mutat az adott innováció. Rogers (1995) szerint az újítások a potenciális felhasználók szempontjából öt fö jellemző mentén vizsgálhatók:

- Relatív előny, azaz, az adott újítás milyen mértékben előnyösebb, mint a már létező eljárás, továbbá fontos szempontként említi az adoptálást is, melytöl további előnyöket, esetleg státuszváltozást (emelkedést) várnak a felhasználók. Elmondható, hogy egy újítás potenciális felhasználók számára mutatkozó relatív előnye egyenes arányban van adoptálásának sebességével (Rogers, 1995; Dessewffy \& Galácz, 2002).

- Kompatibilitás, amely az innováció, az újítás összeférhetőségét mutatja meg a potenciális felhasználók értékeivel, szükségleteivel és múltbéli tapasztalásaikkal. Tehát minél nagyobb eltérés figyelhető meg a gondolkodásban, valamint minél több új tudás elsajátítására van szüksége a használónak, annál kevésbé lesz sikeres és gyors ez a folyamat (Rogers, 1995; Czizmadia, 2017).

- Komplexitás, azaz a közérthetőség foka, mely rámutat arra, hogy egy innováció annál komplexebb, minél több időre van szükség az adoptálásához (Rogers, 1995; Dessewffy \& Galácz, 2002; Csizmadia, 2017).

- A kipróbálhatóság mértéke, amely rávilágít a tanulási folyamatot erősítő kockázatmentes kísérletezgetés fontosságára. Vagyis, minél több formában, platformon tudják a felhasználók kipróbálni az újítást, annál gyorsabb ütemet vesz fel az adoptálás maga (Rogers, 1995; Dessewffy \& Galácz, 2002; Csizmadia, 2017).

- Végül pedig a megfigyelhetőség, amely az újítás átláthatóságát, valamint egyértelmüségét vizsgálja. Elmondható, hogy a megfigyelhetőség mértéke és az adoptálás sebessége egymással egyenesen arányos (Rogers, 1995; Dessewffy \& Galácz, 2002; Csizmadia, 2017).

A fenti jellemzők alapján Rogers (1995) az újdonságok felhasználóit öt csoportba sorolta és egy S-görbén jelenítette meg (1. ábra).

1. ábra

\section{Rogers-féle újítást elfogadók csoportosítása}

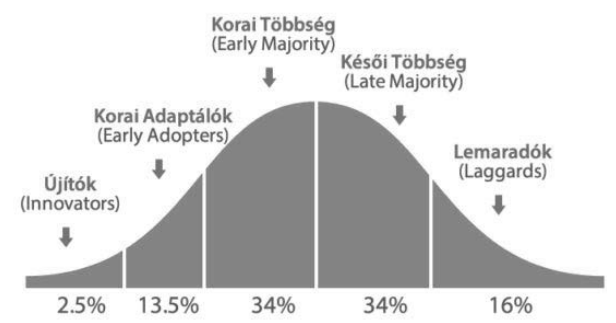

Forrás: Rogers (1995) alapján saját szerkesztés
Az úgynevezett első kipróbálok vagy innovátorok jelentős kockázatot vállalnak, hiszen korábbi tapasztalatok nem állnak rendelkezésre egy adott fejlesztés kapcsán. Öket követik a sorban a korai adaptálók, akiket szintén nyitottság és az újdonságot kedvelő magatartás jellemez, számukra sokszor presztízskérdés, hogy elsőként birtokoljanak vagy próbáljanak ki egy új terméket vagy szolgáltatást ( $\mathrm{pl}$. influencerek, trendkövetök), továbbá tisztában vannak azzal is, hogy a környezetüket alapvetően befolyásolják azzal, amilyen döntéseket meghoznak vagy véleményt kialakítanak és hangoztatnak. Velük szinte közvetlen kapcsolatban van az úgynevezett korai többség, akik tulajdonképpen nyitottak az innovatív megoldásokra, újdonságokra, a fogyasztói döntés meghozásához viszont már szükségük van segítségre, külső hatásra, mások tapasztalataira, egy referenciacsoportra. Velük szemben helyezkedik el a késői többség, akik már alapvetően nehezebben állnak át a jól ismert megoldásokról. Ez a csoport jellemzően megvárja, hogy egy új termék általánosan elterjedjen és felhalmozódjon a felhasználással kapcsolatos információ. Őket követi a sorban a lemaradók vagy sereghajtók rétege, akik az innovációt csak akkor veszik igénybe, ha a korábbi termék vagy szolgáltatás már nem elérhető. Ennek a fajta fogyasztói magatartásnak számos oka lehet: a generációk közti különbség, a bizalmatlanság és a kényelem általában a leggyakoribbak, de az sem elképzelhetetlen, hogy ezt a csoportot kevésbé tudja elérni az adott szolgáltató marketing- és piaci tevékenysége (Rogers, 1995; Dessewffy \& Galácz, 2002; Csizmadia, 2017).

Láthatjuk tehát, hogy az újdonságok kipróbálását jellemző fogyasztói magatartás jelentősen befolyásolja az innovatív megoldások elfogadásának mértékét. A mai fogyasztók azonban már nemcsak a fentebb említett tényezők mentén jellemezhetök. Mindenképp fontos foglalkozni az egyes generációs hatásokkal, melyek véleményünk szerint nagymértékben kihatnak az újdonságok elfogadási szokásaira is.

\section{Generációk}

A generációkat a közös tapasztalatok, életélmények, a közös értékek füzik össze. Az összekapcsolódás laza szálú, de meghatározó (Töröcsik, 2009). Az egyes generációk eltérö értékeivel, hiedelmeivel Mannheim (1928) foglalkozott először, az ő feltételezése szerint az embereket életük végéig meghatározza, hogy fiatal korukban milyen benyomásokat szereznek (Bokor, 2007).

A generációk viselkedésének vizsgálatával 1971 óta foglalkozik a Yankelovich riport címen készülő kutatássorozat az Egyesült Államokban (Yankelovich monitor). A generációkban rejlő alapélmények kutatásának, megragadásának célja, hogy felszínre hozza, azokat a mély, belső hiedelmeket, értékeket, amelyek összekapcsoljak az egy kohorszba tartozó egyéneket (Gergátz, 2009).

Ebben a tanulmányban a két idősebb generációval foglalkozunk (lásd 1. táblázat), akik a Yankelovich riport szerint az érettek (1909-1945 között születtek), valamint a baby boomerek (1946-1964 között). 
1. táblázat Az érettek és a baby boomerek jellemzői

\begin{tabular}{|c|c|c|}
\hline Jellemzők & érettek & baby boomerek \\
\hline $\begin{array}{c}\text { Meghatározó } \\
\text { fogalom az } \\
\text { életükben } \\
\end{array}$ & kötelesség & egyéniség \\
\hline Ünnepelendő & a győzelem & a fiatalság \\
\hline A siker titka & $\begin{array}{c}\text { keményen } \\
\text { megdolgoztam érte }\end{array}$ & $\begin{array}{l}\text { megszülettem, } \\
\text { tehát nyertem }\end{array}$ \\
\hline Stílus & csapatjátékosok & maguknak valók \\
\hline $\begin{array}{c}\text { Jutalom azért jár, } \\
\text { mert }\end{array}$ & megdolgoztam érte & megérdemlem \\
\hline A munka & $\begin{array}{l}\text { elkerülhetetlen } \\
\text { kötelesség }\end{array}$ & izgalmas kaland \\
\hline A meglepetés & lehet jó és rossz is & valami jót jelent \\
\hline A szabadidő & $\begin{array}{l}\text { a kemény munka } \\
\text { jutalma }\end{array}$ & az élet célja \\
\hline A továbbtanulás & csak egy álom & velem született jog \\
\hline A jövő & $\begin{array}{l}\text { az, amiért elöre } \\
\text { meg kell dolgozni }\end{array}$ & $\begin{array}{l}\text {-nél a „most” } \\
\text { fontosabb }\end{array}$ \\
\hline A pénzt & félreteszik & elköltik \\
\hline
\end{tabular}

Forrás: Smith \& Clurman (2003). Generációk, márkák, célcsoportok (Gergátz, 2009)

Az amerikai kutatások alapján elmondhatjuk, hogy az érett generáció (1909-1946) kategóriája további két alkategóriára bontható: a veteránokra és a csendesek csoportjára. A veteránok életében a legfőbb cél, hogy rendes ember váljon belölük, míg a csendesek óvatosabbak, visszahúzódóbbak, jobban szeretnek a háttérben maradni (Gergátz, 2009). A baby boomer generáció (1945-64) a lázadó generáció. Jobb oktatásban volt részük, önálló véleményük van, úgy érzik, hogy szüleiknél jobban tudják és értik a dolgokat. Az önmegvalósítást tartják életük legfőbb vágyának, ami tetten érhető a munkában, valamint a szabadidö-eltöltésben is (Gergátz, 2009). Jellemző még rájuk, hogy később házasodnak, magas körükben a válási arány, valamint elérték a keresőképességük csúcsát, de anyagi helyzetük nem teszi lehetővé, hogy nyugdíjba vonuljanak.

A magyar társadalom hat generációból épül fel: veteránok, baby boomerek, X generáció, Y generáció, Z generáció és az alfák (Eyerman \& Turner, 1998; Mannheim 1928; Tari, 2014). Az amerikai generációs csoportokkal egybevetve az éretteknek a veteránok (Tari, 2014), a baby boomereknek pedig a Ratkó-korszak szülöttei a hazai megfelelői. Megjegyzendő, hogy a szakirodalomban kissé eltérő korbeosztásokkal találkozunk.

A magyar generációk meghatározó élményeivel foglalkozott Törőcsik is (2003, idézi Gergátz, 2009), melyet a 2. táblázatban ismertetünk.

Törőcsik és Lampek (2016) kutatásai alapján az 50 felettiek véleménye szerint átlagosan a 72,8 évesek számítanak öregnek, a középkorú (45-60) férfiak szerint átlagosan 67,5 év, a középkorú nők (45-60) szerint 71,2 év, az időskorú férfiak (60+) szerint 75,3 év, az időskorú nők $(60+)$ szerint pedig 77,4 év az a kor, amikortól valaki öregnek számít.
2. táblázat A veteránok és a Ratkó-korszak szülőtteinek jellemzői

\begin{tabular}{|c|c|c|}
\hline & Veteránok & $\begin{array}{c}\text { Ratkó-korszak } \\
\text { szïlöttei }\end{array}$ \\
\hline $\begin{array}{l}\text { Meghatározó } \\
\text { élmény }\end{array}$ & háború & $\begin{array}{l}\text { kisdobos, úttörö, } \\
\text { KISZ tagság }\end{array}$ \\
\hline Pozitív élmények & „fényes szelek” & $\begin{array}{c}\text { „legvidámabb ba- } \\
\text { rakk" }\end{array}$ \\
\hline Negatív élmények & $\begin{array}{l}\text { kuláküldözés, } \\
\text { kitelepítés, padlás- } \\
\text { söprés }\end{array}$ & olajválság \\
\hline Felvonulás & 1956 & május 1-i felvonulás \\
\hline A világ & kétpólusú & $\begin{array}{c}\text { nemzetközi építö- } \\
\text { tábor }\end{array}$ \\
\hline Lakáshelyzet & társbérlet & panellakás \\
\hline
\end{tabular}

Forrás: Törőcsik (2003 in Gergátz, 2009)

Magyarországon 2013-ban a férfiak születéskor várható átlagos élettartama 73,58 év volt, míg a nőké 78,39. A budapestiek az országos értékeknél kedvezőbb élettartam-kilátásokkal rendelkeznek. A demográfiai helyzet magyar sajátossága, hogy a tartósan alacsony termékenységhez mind a mai napig tartósan magas halandóság társul (Gergátz, 2009).

Hazánkban a férfiak és a nők várható élettartama közötti nagy különbség következtében számos nő marad özvegyen idősebb korára. Ezért az idősebb egyedül élők nők aránya magas, miközben alacsony a partnerükkel élöké. Ez a minta nagyon hasonló a többi kelet-európai országban, ugyanakkor különbségek is láthatóak. Egyébiránt, Magyarországon a legkisebb, Szlovákiában a legnagyobb az olyan háztartásszerkezetben élők aránya, amely többnyire a gyermekeikkel élő idősek együttélési formáit fedi le (Eurostat, 2011).

\section{Fogyasztói mintázatok}

Ha figyelembe vesszük az elöregedés tényét és nagyságát, annak gazdasági és a társadalmi vonaktozásaival együtt, akkor érdemes megvizsgálni az idősebbek fogyasztói mintázatait is! Minden korosztály fogyasztói magatartását befolyásolja a biológiai, a társadalmi, a pszichológiai illetve a gazdasági dimenzió (Kennett et al., 1995; Lumpkin et al., 1985; Deloitte, 2005 in Kolos, 2014). A biológiai dimenzió az emberi szervezet változására utal, arra, hogy idővel a látás, a szaglás, valamint a hallás is gyengül. Ezek a folyamatok tetten érhetőek a külső környezet észlelésében, illetve a reklámüzenetek elhelyezéssel kapcsolatban (például nagy betümérettel rendelkező honlapok az idősebb, de rosszullátók számára stb.). A pszichológiai dimenzió a kognitív képességek változását foglalja össze (pl.: az információk tartalommá való összesítésében). Az idősebb generáció gazdasági helyzete is átalakul (hiszen válhat jobbá megtakarítások által, és válhat rosszabbá ha nyugdíj nagysága nem fedezi az alapvető költségeiket), erre utal a gazdasági dimenzió (Kolos, 2014).

Törőcsik és Németh (2018) kutatásukban többféle változóval mérték fel az egész társadalom életstílusát, fogyasztását. Tanulmányunk szempontjából számunk- 
ra azok a jellemzők fontosabba, amelyek szignifikánsak voltak az idősebb válaszadókra tekintve. Az idősebb generációnak az ,egészében véve élvezem az életemet”, az ,elég egészséges vagyok ahhoz, hogy független maradjak”, illetve „,meg vagyok elégedve azzal, amit csinálok”, valamint ,biztonságban érzem magam, ahol élek" attitűdállításokra adott válaszai szignifikánsan magasabbak, mint más generációké. Az információs technológia szerepét vizsgálva kiemelendő, hogy pont ebben nyitnak lehetőségeket a Skype, Facebook és egyéb kommunikációs eszközök. Az idős generáció a fentebb említett kapcsolatteremtési internetes eszközök kezelését igyekszik is megtanulni, és ők tartják a legtöbb emberrel telefonon is a kapcsolatot (Törőcsik \& Németh, 2018).

Heterogenitása miatt az idősebb generáció (55+) több alszegmensre is bontható. Kolos (2014) 600 fös idősekkel foglalkozó kutatásában a következő fogyasztói klasztereket különböztette meg:

- változatosságkereső: szeret új termékeket kipróbálni, figyel a divatra, keresi a külső fogódzókat, a reklámokból és az árakból is igyekszik következtetéseket levonni (26\%),

- a vásárláshoz negatívan viszonyuló: a fő megkülönböztető vonása, hogy a vásárlást kellemetlennek, időpocsékolásnak érzi, ha vásárol, az átlagosnál valamivel megfontoltabb, és igyekszik mindig ugyanazokat a márkákat venni, ugyanabba a boltba menni (31\%),

- alacsony érdekeltségü: ez a típusú fogyasztó nem törődik sokat a vásárlásaival, nem tépelődik a döntés előtt, nem keresi a változatosságot, nem figyel a külső jelzésekre (ár vagy reklám), ha teheti ugyanazt a márkát veszi, feltehetőleg praktikus szempontok miatt és valamivel kisebb árérzékenység jellemzi, mint a többieket (21\%),

- a mérlegelö: nem dönt elhamarkodottan, igyekszik kedvező árért jó minőséget venni, ennek feltehetően utána is jár, mert a márkahűség nem jellemző rá, a vásárlás szórakoztatja (22\%).

Ezek az eltérő jellemzők jelentős befolyást gyakorolhatnak az innováiós nyitottságra is.

\section{Az idősek és az információs technológa kapcsolata}

\section{Használati jellemzők}

A hazai felmérés eredményeit nézve a technológiához való viszonyról (Kolos, 2014) az idős válaszadók a szabadidő-eltöltés nagyságáról úgy nyilatkoztak ( $\mathrm{n}=600)$, hogy a leggyakrabban végzett tevékenységek a tv-nézés (a megkérdezettek 68 százaléka gyakran néz televíziót), ezt követi a napilapolvasás (64 százalék) és a rádióhallgatás (59 százalék). A soha nem végzett tevékenységek között legnagyobb arányban az internetezés állt, habár az internetezés terén a megkérdezettek 23 százaléka jelezte, hogy gyakran ül a gép elé.

A 3. táblázat ismerteti, hogy hogyan is oszlott meg 2017-ben a számítógép-használat korcsoportokra bontva. Látható, hogy ahogy az egyre idősödő korcsoportok felé haladunk, úgy csökken a naponta számítógépet használók aránya. A Ratkó-korszak szülöttei esetében ez 81,5 százalék, míg a veteránok esetében 72,3 százalék. A két generáció között 9,2 százalék különbség figyelhető meg. Itt jegyezzük meg, hogy természetesen a 81,5 százalék elég magas arány, viszont a közel 10 százalékos lemaradás, amely a veteránok esetében figyelhetö meg, magasnak mondható (KSH, 2017).

3. táblázat

A számítógép-használat gyakoriságának megoszlása korcsoporton, iskolai végzettségen és lakóhelyen belül 2017-ben százalékban

\begin{tabular}{|c|c|c|c|c|}
\hline $\begin{array}{c}\text { Megneve- } \\
\text { zés }\end{array}$ & $\begin{array}{c}\text { Naponta } \\
\text { használók }\end{array}$ & $\begin{array}{c}\text { Hetente } \\
\text { használók }\end{array}$ & $\begin{array}{c}\text { Havonta } \\
\text { használók }\end{array}$ & Összesen \\
\hline Összesen & $\mathbf{8 8 , 5}$ & $\mathbf{9 , 6}$ & $\mathbf{1 , 9}$ & $\mathbf{1 0 0 , 0}$ \\
\hline \multicolumn{5}{|c|}{ Életkor szerint } \\
\hline $16-24$ & 95,7 & 3,4 & 0,9 & $\mathbf{1 0 0 , 0}$ \\
\hline $25-34$ & 92,7 & 6,7 & 0,6 & $\mathbf{1 0 0 , 0}$ \\
\hline $35-44$ & 90,1 & 8,6 & 1,3 & $\mathbf{1 0 0 , 0}$ \\
\hline $45-54$ & 86,8 & 11,4 & 1,8 & $\mathbf{1 0 0 , 0}$ \\
\hline $55-64$ & $\mathbf{8 1 , 5}$ & $\mathbf{1 4 , 5}$ & $\mathbf{3 , 9}$ & $\mathbf{1 0 0 , 0}$ \\
\hline $65-74$ & $\mathbf{7 2 , 3}$ & $\mathbf{2 1 , 5}$ & $\mathbf{6 , 2}$ & $\mathbf{1 0 0 , 0}$ \\
\hline
\end{tabular}

Forrás: KSH (2017) alapján saját szerkesztés

\section{Az internethasználat gyakoriságának megoszlása életkor szerint}

\begin{tabular}{|c|c|c|c|c|c|c|c|c|c|}
\hline \multirow{2}{*}{ Megnevezés } & \multicolumn{3}{|c|}{ Naponta Hetente } & \multicolumn{3}{c|}{ Havonta } & \multicolumn{3}{c|}{ Összesen } \\
\cline { 2 - 10 } & 2016 & 2017 & 2016 & 2017 & 2016 & 2017 & $\mathbf{2 0 1 6}$ & $\mathbf{2 0 1 7}$ \\
\hline Összesen & $\mathbf{8 9 , 2}$ & $\mathbf{8 9 , 5}$ & $\mathbf{9 , 3}$ & $\mathbf{9 , 1}$ & $\mathbf{1 , 5}$ & $\mathbf{1 , 5}$ & $\mathbf{1 0 0 , 0}$ & $\mathbf{1 0 0 , 0}$ \\
\hline \multicolumn{8}{|c|}{ Életkor szerint } \\
\hline $16-24$ & 95,2 & 96,9 & 4,7 & 3,0 & 0,1 & 0,1 & $\mathbf{1 0 0 , 0}$ & $\mathbf{1 0 0 , 0}$ \\
\hline $25-34$ & 93,8 & 93,9 & 5,5 & 5,2 & 0,8 & 0,9 & $\mathbf{1 0 0 , 0}$ & $\mathbf{1 0 0 , 0}$ \\
\hline $35-44$ & 91,9 & 90,6 & 7,7 & 8,8 & 0,4 & 0,6 & $\mathbf{1 0 0 , 0}$ & $\mathbf{1 0 0 , 0}$ \\
\hline $45-54$ & 89,1 & 88,0 & 9,2 & 10,8 & 1,7 & 1,2 & $\mathbf{1 0 0 , 0}$ & $\mathbf{1 0 0 , 0}$ \\
\hline $55-64$ & $\mathbf{8 1 , 3}$ & $\mathbf{8 2 , 1}$ & $\mathbf{1 5 , 4}$ & $\mathbf{1 4 , 3}$ & $\mathbf{3 , 2}$ & $\mathbf{3 , 6}$ & $\mathbf{1 0 0 , 0}$ & $\mathbf{1 0 0 , 0}$ \\
\hline $65-74$ & $\mathbf{6 9 , 1}$ & $\mathbf{7 3 , 1}$ & $\mathbf{2 4 , 2}$ & $\mathbf{2 1 , 2}$ & $\mathbf{6 , 6}$ & $\mathbf{5 , 7}$ & $\mathbf{1 0 0 , 0}$ & $\mathbf{1 0 0 , 0}$ \\
\hline
\end{tabular}

Forrás: KSH (2017) alapján saját szerkesztés 
A gyakran végzett szabadidős tevékenységek és a demográfiai változók közötti összefüggéseket tekintve (4. táblázat) azt mondhatjuk, hogy szignifikánsan eltér az 50 és 64 év közöttiek internethasználata, összevetve a 65 év felettiekkel. A hivatalos hazai statisztikai adatok alapján is azt mondhatjuk, hogy valóban van eltérés - bár nem számottevően - a számítógép-használat, iletve az internethasználat gyakoriságában a két érintett korcsoport között (KSH, 2017).

A netező idősebbek (mindkét generációra vonatkozatva) eszközhasználat terén elég aktívnak bizonyultak: 33 százalék egy, 37 százalék kettő, 30 százalék pedig három vagy több internetezésre alkalmas eszközt is használ. Ezek közül az okostelefon a leggyakoribb (55\%), ezt követi az asztali számítógép (54\%), a laptop (49\%), a tablet (27\%) és az okostévé (22\%) (eNet, 2018).

Az idős válaszadók szerint a netező idősek (venetárok és Ratkó-korszak szülöttei) inkább hasznos tevékenységekre használják a netet (43 százalék), 37 százalékuk szerint pedig hasznos tevékenységekre és szórakozásra egyaránt. A napi szinten végzett online tevékenységek esetében a böngészés (42\%), a közösségimédia-oldalak látogatása (42\%), a csetelés (35\%) és a hírolvasás $(34 \%)$ a legjellemzőbb. A digitálisan igazán aktív idősök a fentiek mellett számítógépes játékokat is szoktak a családdal játszani $(27 \%)$ és videótelefon-szolgáltatást is használnak (14\%) (eNet, 2018).

A kutatások azt jelzik, hogy a népesség elöregedésével párhuzamosan az idősebb korosztály az online platformokon is egyre markánsabban képviselteti magát, de még mindig jóval alacsonyabb az internetezéssel töltött idejük más generációkkal összehasonlítva (Niehaves \& Plattfaut, 2014).

A növekvő érdeklődés okai között megemlíthetők a szabadon és aktív módon eltölthető idő növekedése, az online aktivitás által a látókör kiszélesítésének lehetősége, az érdeklődési körök bővülése, az elönyök felismerésével a kezdeti félelmek és negatív attitüdök megváltozása, az online jártasság elsajátításának igénye, vagy akár bizonyos élethelyzetekhez (pl. gyerekek, unokák külföldön való tartozkódása) kapcsolódóan annak szükségessége. Iyer és Eastman (2016) eredményei alapján napjainkban az idősebbek szórakoztatónak, hatékonynak, kényelmesnek tartják az internetezést.

Az infokommunikációs eszközök idősek számára nyújtható használati előnyeivel foglalkozó kutatások kiemelik, hogy ezek segíthetik az elszigetelten élő idős embereket abban, hogy társadalmi kapcsolatokat, barátságokat építsenek ki (White et al., 1999). A digitális közösségekhez való csatlakozás révén ez azért nagyszerü lehetőség, mert ebben az életkorban erre másképp már kevés lehetőség adódna (Kanayama, 2003). Továbbá az infokommunikációs eszközökhöz kapcsolható online tevékenységek szellemi stimulációt jelentenek idős korban (Ogozalek, 1991). Elősegítik a folytonos tanulást, emellett szórakozási lehetőséget is teremtenek (Adler, 2006). További előny, hogy javul a generációk közötti kommunikáció (Furlong, 1995), és az, hogy az információs eszközök segítségével az idősek tovább tudnak függetlenek, önellátóak maradni (egészségügyi applikációk, foglalások és egyéb egészségmegőrző digitális eszközök által).

Az AARP (2017) egy független, 50 évnél idősebbek kutatásával foglalkozó intézet. Az egyesült államokbeli idősekre vonatkozó 2017-es kutatásuk vezetői összefoglalójában kiemelték, hogy a mobil- és a hagyományos (asztali számítógép) eszközök használata az 50 évnél idősebb generációnál is megjelenik. A válaszadók nagy többsége (91\%) úgy nyilatkozott, hogy a technológia segített nekik kapcsolatot fenttartani másokkal. A 70 százalékuk fent van valamelyik közösségi oldalon, de csak 18 százalékuk biztos abban, hogy az online oldalakon megadott adatuk biztonságos. A Pew Research Center felmérései alapján (2016) a 65 évesnél idősebbek 2/3-a naponta felmegy az internetre (asztali számítógépen), és bár az okostelefonbirtoklók nagysága 42 százalék, a kutatók állítják, hogy sok idős marad távol a digitális élettől.

\section{A veteránok és a baby boomerek internethasználati szokásai}

A korábban bemutatott, 2018-as egyesült államokbeli országos kutatás alapján azt lehet megállapitani, hogy a két idősebb generáció - baby boomerek és veteránok - internetezési hajlandósága és szokásai eltérőek.

A Pew Research Center által végzett 2018-as kutatás eredményében azt olvashatjuk, hogy a baby boomerek 67 százaléka birtokol okostelefont, míg a veteránoknak csak a 30 százaléka. Szintén hasonlóan eltérö eredményeket találunk, amikor a Facebook-használatról kérdezik a válaszadókat: a baby boomerek 59 százaléka használja, amíg veteránok 26 százaléka. Az Y generáció és az X generáció ebben a kérdésben közelít egymáshoz, körükben hasonló a Facebook-aktivitás nagysága. Az viszont megfigyelhetö, hogy a baby boomerek felvették a ritmust a technológia használatában, mert 2011-ről 2018-ra jócskán megugrott a használat mértéke, ami nem mondható el a veteránokról. Sőt, ha azt nézzük, hogy az egyes generációs csoportok miképp vélekednek magáról az internetről és a pozitív társadalmi hasznáról, akkor szintén nagyok az eltérések. Az Y és X, valamint a baby boomer generáció szinte ugyanannyira pozitívan ítéli meg az internet társadalmi hasznát, amíg a veteránok az internetezés pozitív jelentőségét saját magukra és a társadalomra vetítve is sokkal alacsonyabbnak tartják (Pew Research Center, 2018).

A későbbiekben bemutatott saját primer kutatásunkban is feltételezzük, hogy az érettek (veteránok) és a baby boomerek (Ratkó ,gyerekek”) internethasználati szokásai, innovációelfogadási atittüdje eltér, hiszen más életszakaszban érte el őket az információs technológia megjelenése.

Az idősebbeken (55+ kategória) belül két generáció veteránok, illetve a Ratkó-korszak szülöttei - információtechnológia használati szokásaira tértünk ki az elméleti összefoglalásban azért, hogy megfelelően fel tudjuk tárni azokat az árnyalatnyi különbségeket, amelyek az online magatartásban felmerülhetnek, és amelyekre kitérünk primer kutatásunk során. 


\section{A primer kutatás}

\section{A kutatás célja és módszertana}

Kutatásunk célja az volt, hogy megvizsgáljuk a nyugdíjas korosztály internethasználati szokásait, továbbá feltárjuk azokat a tényezőket, melyek meghatározzák az ebben rejlő különbségeket. Kutatásunk fókuszában az életkor (generációk) és az innovativitás kapcsolatának vizsgálata állt.

Kutatási kérdéseink a következők voltak: A célcsoportra milyen médiahasználati szokások jellemzöek? Mennyi idöt töltenek televíziózással, illetve internetezéssel? Ha interneteznek, akkor egyes tevékenységeket milyen gyakran végeznek? A közösségi oldalakon milyen aktivitás jellemzö rájuk? Mi jellemzö az internetes hírfogyasztási szokásaikra, milyen forrásokat tartanak hitelesnek?

Elemzésünkhöz kvantitatív kutatást végeztünk. Az adatfelvétel 2018. január 25. és február 14. között két fázisban zajlott 1213 és 1406 fö megkérdezésével. A megkérdezés online kérdőív segítségével történt, a válaszadók rekrutálásához pedig közösségimédia-felületen megjelenő hirdetést használtunk. Célcsoportunk az internetező nyugdíjas korosztály volt. A mintába kerülés feltételeinél egyszerüsítéssel éltünk, mintánkat azok alkotják, akik nyugdíjasok és legalább 55 évesek, avagy egyéb aktivitásúak, de legalább 65 évesek. A minta fóbb demográfiai jellemzőit az 5. táblázat foglalja össze.

\section{A minta főbb demográfiai jellemzői}

5. táblázat

\begin{tabular}{|c|c|c|c|}
\hline \multicolumn{2}{|r|}{ Demográfiai jellemzők } & Darab & Százalék \\
\hline \multirow{2}{*}{ Nem } & Férfi & 1244 & 47,5 \\
\hline & Nö & 1375 & 52,5 \\
\hline \multirow{5}{*}{ Életkor } & $55-59$ éves & 52 & 2,0 \\
\hline & 60-64 éves & 433 & 16,5 \\
\hline & 65-69 éves & 1123 & 42,9 \\
\hline & 70-74 éves & 683 & 26,1 \\
\hline & $75+$ éves & 328 & 12,5 \\
\hline \multirow[b]{2}{*}{$\begin{array}{l}\text { Generá- } \\
\text { ció }\end{array}$} & Veteránok & 543 & 20,7 \\
\hline & $\begin{array}{c}\text { Ratkó-korszak szülöttei (baby } \\
\text { boomerek) }\end{array}$ & 2076 & 79,3 \\
\hline \multirow{5}{*}{$\begin{array}{l}\text { Iskolai } \\
\text { végzett- } \\
\text { ség }\end{array}$} & Legfejlebb nyolc általános & 37 & 1,4 \\
\hline & Szakmunkásképzős, szakiskola & 318 & 12,1 \\
\hline & Érettségi & 1150 & 43,9 \\
\hline & Diploma vagy magasabb & 1093 & 41,7 \\
\hline & Nincs adat & 21 & 0,8 \\
\hline \multirow{5}{*}{$\begin{array}{l}\text { Lakó- } \\
\text { hely }\end{array}$} & Budapest & 598 & 22,8 \\
\hline & Megyeszékhely & 554 & 21,2 \\
\hline & Egyéb város & 838 & 32,0 \\
\hline & Község & 518 & 19,8 \\
\hline & Nincs adat & 111 & 4,2 \\
\hline
\end{tabular}

Forrás: saját szerkesztés

\section{A kutatás eredményei}

Az egyes internethasználati szokásokat több változó mentén vizsgáltuk, ugyanakkor analízisünk alapvetően a generációs és a válaszadók innovativitásából adódó különbségek feltárására koncentrált. A részletes eredmények ismertetése előtt bemutatjuk a megkérdezettek innovativitással kapcsolatos jellemzőit.

\section{Innovativitás}

A válaszadókat innovativitás szempontjából a rogersi (Rogers, 1995) kategóriákba soroltuk. A csoportosítást az alapján végeztük el, hogy a megkérdezettek mikor (melyik évben) kezdtek el internetezni.

Az innovátorokat és a korai adaptálókat összevontuk egy csoportba, melyre az alkalmazott kérdés jellege miatt volt szükség. A két kategória összevonása Rogers szerint is alkalmazható (Rogers, 1995). A válaszadóknak vissza kellett emlékezniük arra, hogy melyik évben kezdtek el internetezni. Az évszám pontos meghatározása - fóleg a világhálót régóta használók esetében - nehézségekbe ütközhet. E bizonytalansággal számolva nem tartottuk célszerünek az innovátorokat a teljes mintából 2,5 százalékot kitevő arányuk miatt elkülöníteni a korai elfogadóktól.

Mintánkban e leginnovatívabb csoport összesen 14,7 százalékot tesz ki. A korai többséghez 34,9, a kései többséghez 34,7 százalékukat soroltuk, míg a lemaradók aránya 15,7 százalék.

Az egyes kategóriákba tartozók közötti különbségeket vizsgálva szignifikáns $(\mathrm{p}=<0.05)$ eltéréseket azonosítottunk a nem, az iskolai végzettség és az anyagi helyzet alapján.

A férfiak körében több az innovatívabb válaszadó (innovátorok és korai adaptálók 16,3\%, a nőknél 13,3\%), míg nők közül többen tartoznak a lemaradók közé $(17,7 \%$, férfiak esetében 13,4\%). Ennél jelentősebb különbségek mutatkoznak az iskolai végzettségben és az anyagi helyzetben. Mindkét változó esetében a magasabb értékkel együtt nő az innovativitás is (2. ábra).

2. ábra

\section{Innovativitás iskolai végzettség és anyagi helyzet függvényében (százalék)}

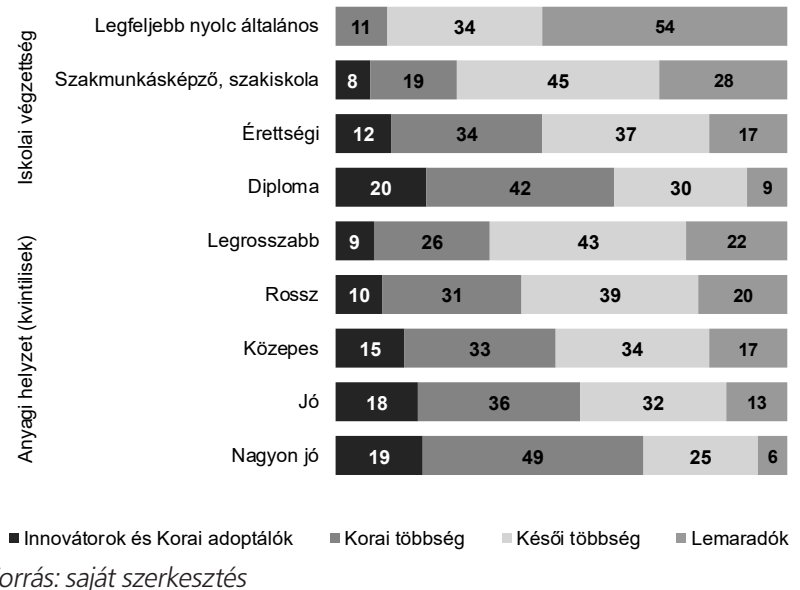

A két vizsgált generációról annyi különbség állapítható meg, hogy a veteránok között valamivel magasabb a leginkább és a legkevésbé innovatívabbak aránya is, mint a Ratkó-korszak szülöttei körében (sorban: 18,6\% vs. 13,7\% és $17,8 \%$ vs. 15,1\%). A generációkon belül vizsgálva a nem, az iskolai végzettség és az anyagi helyzet szerinti 
bontást vizsgálva is hasonló tendenciák érvényesülnek, mint a teljes minta esetében.

\section{Egyes médiumokkal töltött idő}

A TV-nézésre, az internetezésre és a közösségi oldalak használatára fordított időt sorrendi skálával mértük. Az egyes csoportok közötti összehasonlítás érdekében a változót átkódoltuk, úgy, hogy annak percben kifejezhető értéke legyen. Ez a technika számos aggályt vet fel, így hangsúlyozandó, hogy csak becslésként értelmezhetö, alapvető célja az egyes különbségek érzékeltetése. Megjegyzendő, hogy a módszer használata ugyanakkor nem egyedi, pl. Székelyi \& Barna (2004), illetve Antalóczy és társai (2017) a médiahasználati szokások vizsgálatánál ugyanezt a módszert alkalmazták. Az így kapott eredmények szerint a megkérdezettek egy nap átlagosan 146 percet töltenek tévénézéssel, 161 percet internetezéssel, míg 118 percet közösségi oldalak használatával.

Összehasonlításként a Nielsen Közönségmérés 2018. februári müszeres mérésen alapuló statisztikái szerint a teljes népesség körében a televíziózásra fordított napi idő átlaga 303 perc volt. Az 50-59 év közöttiek körében ez 360 perc, míg a 60 év felettiek körében 452 perc. Tehát a mintánkban szereplők életkora miatt magasabb értéket várhatnánk, ugyanakkor az egyéb jellemzők ezzel ellentétesen hatnak. A megkérdezettjeink között felülreprezentáltak az érettségizettek és a diplomások, akik a teljes népesség esetében sorban 298, illetve 237 percet fordítottak erre a tevékenységre. Hasonló tendencia figyelhető meg a települések típusát vizsgálva is. Mintánk szempontjából - mivel csak internetezőket kérdeztünk meg - az internethasználatnak is jelentősége van a televíziónézésre. A Nielsen adatai szerint a teljes népességen belül azok, akik nem használnak otthon netet, átlagosan 438 percet tévéztek, az asztali PC-n netezők 341 percet, míg az erre a célra hordozható eszközt (is) használók csupán 250 percet.

Eredményeinkből egyértelmüen kirajzolódik az a fentebb is ismertetett összesfüggés, miszerint az internetezési idővel csökken a tévénézésre fordított idő. A két vizsgált generáció között csak az internetezés esetében mértünk szignifikáns különbséget, de ennek mértéke mindössze tíz perc (Ratkó-korszak szülöttei 164 perc, veteránok 154 perc). Az innovativitási kategóriák szerint vizsgálva az eredményeket egyértelmű különbségek mutatkoznak az internetezésre fordított idő tekintetében: minél innovatívabb a válaszadó, annál többet időzik a világhálón. A televíziózás esetében a két kevésbé innovatív csoportba tartozóknál láthatók eltérések (3. ábra), ők több időt fordítanak erre (átlagosan 18 perceel többet, mint a két innovatívabb csoport). A közösségi oldalak használatában nincs eltérés az egyes csoportok között. Az egyes generációkat külön vizsgálva a teljes mintán is érvényesülö trendet láthatjuk.

3. ábra

\section{Átlagos napi időtöltés (perc)}

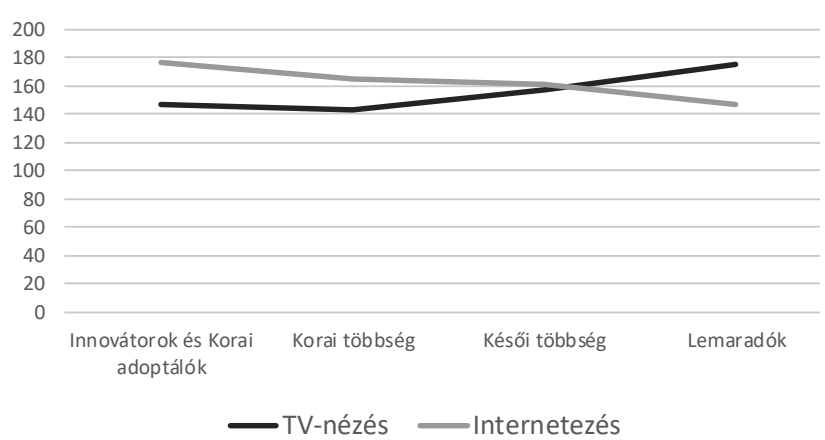

Forrás: saját szerkesztés

Az egyes médiumokra fordított idő függ attól is, hogy a megkérdezett egyedül él-e. Az egyedül élők többet tévéznek (átlagosan napi húsz perccel), mint a nem egyedül élők, az internethasználatban nincs kimutatható különbség, viszont a közösségi oldalakat is többet használják (átlagosan napi 17 perccel). Ha az innovativitást is bevonjuk az elemzésbe, kiderül, hogy az egyes csoportok esetében más médium mellett teszik le voksukat az egyedülállók (itt megjegyzendő, hogy az egyedül élők között

Átlagos napi időtöltés (perc)

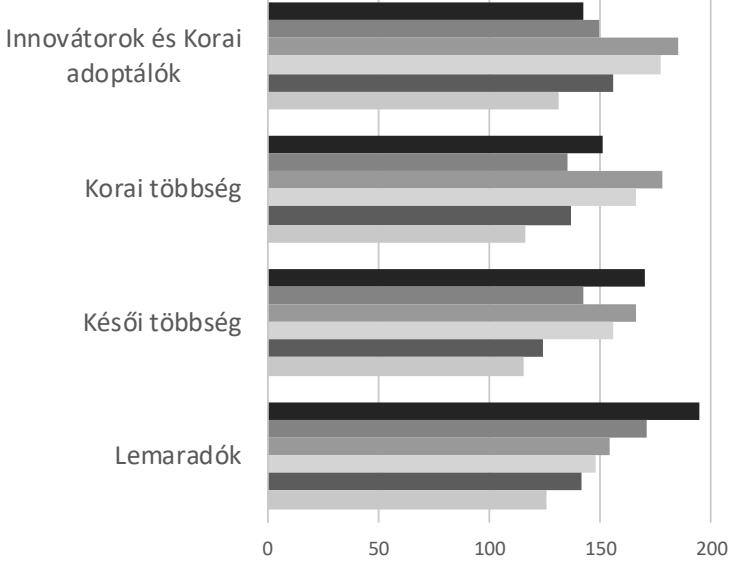

Forrás: saját szerkesztés
- TV-nézés, Egyedül élők

TV-nézés, Nem egyedül élők

- Internetezés, Egyedül élők

- Internetezés, Nem egyedül élők

Közösségi oldal használat, Egyedül élők

Közösségi oldal használat, Nem egyedül élők 
felülreprezentáltak a lemaradók). Bár az eredmények nem minden esetben igazolhatók statisztikailag, a kirajzolódó különbségek feltételezhetően eltérő magatartást is jelentenek (4. ábra). Az innovátorokból és a korai adaptálókból álló csoport egyedülálló tagjai nem tévéznek többet nem egyedül élő társaiknál, viszont többet interneteznek és használnak közösségi oldalt. A korai többség egyedülálló tagjai mindegyik elfoglaltságra több időt szánnak (a televíziózás és a közösségioldal-használat szignifikánsan különbözik). A késői többség esetében a társak nélkül élők szignifikánsan többet tévéznek, míg az internetezésben nincs szignifikáns különbség. Ugyanez rajzolódik ki a lemaradók esetében is, de itt egyik esetben sem igazolhatók az eltérések.

\section{Az internethasználat kezdete}

A megkérdezettek átlagosan 15 éve, 54 évesen kezdtek el internetezni. A Ratkó-korszak szülöttei és a veteránok között nincs eltérés a tekintetben, hogy mennyi ideje léptek először a világhálóra (sorban a mért értékek: 15,0 és 15,7 éve), viszont életkorban ez azt jelenti, hogy a fiatalabb generáció tagjai átlagosan 52 évesen, míg az idősebbek 60 évesen ismerkedtek meg a digitális galaxissal.

Az innovativitás szerinti bontásban vizsgálva azt látjuk, hogy az egyes csoportok átlagos életkora minimálisan különbözik (68-70 év között mozog), ugyanakkor jelentős különbségek mutatkoznak mind abban, hogy az egyes szegmensek tagjai hány éves korukban kezdtek el internetezni, mind abban, hogy hány éve teszik ezt.

Az innovátorok és a korai adaptálók csoportja nagyjából az internet megjelenésével egyidőben el is kezdhette azt használni. A megkérdezettek válaszai itt csak indikátorként értelmezhetők, feltételezhetően a többség csak nagy pontatlansággal tudott a kérdésre válaszolni (átlag 42 évesen, 28 éve). A korai többség a kétezres évek elején a háztartásokban is egyre gyakrabban megjelenő internet korszakában ismerkedhetett meg a világhálóval (átlagosan 50 évesen, 18 éve), de feltételezhetöen itt is viszonylag nagy lehet a bizonytalanság a pontos évszámokat illetően.
A késői többség nagyjából egy évtizede szörföl a weben (átlagosan 57 évesen, 11 éve kezdték használni), míg a lemaradók legfeljebb hét éve teszik ezt, de akad köztük olyan is, akinek ezirányú tapasztalata csak hónapokban mérhető (ők átlagosan 64 évesen, 5 éve kezdték el).

\section{Internetes tevékenységek}

Nyolc különböző internetes tevékenység esetében vizsgáltuk, hogy azokat milyen gyakorisággal végzik a megkérdezettek. Ezek eredményei az 5. ábrán láthatók. Ha az online térben vannak, ezek közül leggyakrabban közösségi oldalakkal és hírek olvasásával töltik idejüket. A legkevésbé népszerü tevékenységek közé (melyek esetében a legtöbb soha választ kaptuk) tartoznak az internetes játékok, de így is hozzávetőlegesen minden második válaszadó szokott így szórakozni, valamint az online telefonálás, amelyet a válaszadók közel 2/3-a szokott legalább néha kapcsolattartáshoz választani. Az internetező nyugdíjasok nagyobb része (71\%) szokott a weben vásárolni, igaz a legtöbben (57\%) csak néha tesznek így.

A demográfiai változók függvényében vizsgálva az látható, hogy - a vártnak megfelelően - a nők valamivel aktívabbak mind az írásbeli, mind a szóbeli online kommunikációban. A két nem között a legjelentősebb különbséget az internetes játékok esetében mértük, a férfiak 54 százaléka sosem szórakozik ily módon, a nők körében ez az arány csupán 41 százalék. Ezzel összhangban a nagyon gyakran játszók aránya a férfiak körében 6 százalék, a nők körében több, mint duplája, 13 százalék.

A gyakori e-mailezés elsősorban a magasabban iskolázottakra és a jobb anyagi helyzetben élőkre jellemző, míg a netes játékok népszerübbek az alacsonyabban iskolázottak körében.

A Ratkó-korszak szülöttei és a veteránok esetében (lásd 6. táblázat) az online kapcsolattartási megoldásokat vizsgálva némi különbség mutatkozik az írásos és szóbeli kommunikációban is, a fiatalabb nyugdíjasok valamivel gyakrabban élnek ezekkel a lehetőségekkel, e-mailt viszont hasonló gyakorisággal használnak. A közösségi

\section{Ha internetezik, milyen gyakran csinálja az alábbiakat? (százalék)}

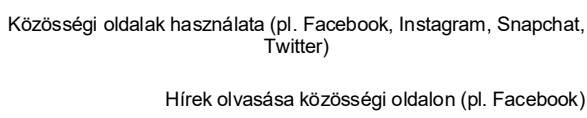

Internetes vásárlás

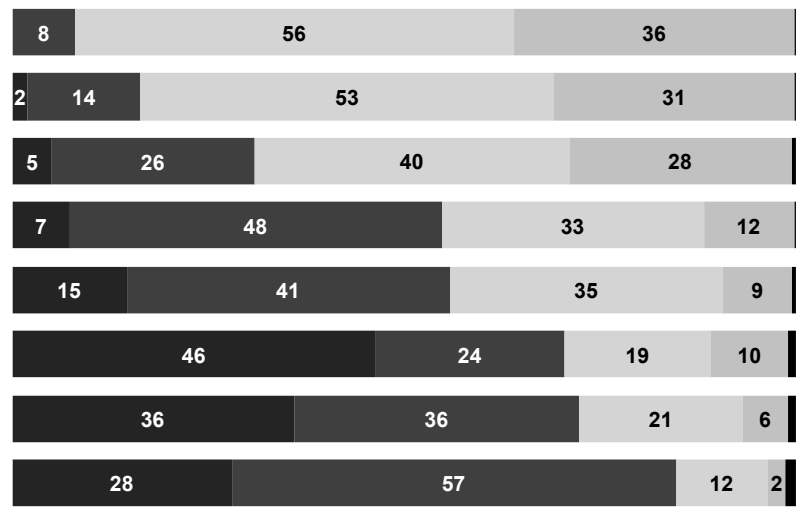

Nagyon gyakran
- Nem tudom/Nem válaszolok 
oldalak valamivel gyakoribb használata jellemző a Ratkó-korszak szülötteire, és ugyanez figyelhető meg a hírek olvasása esetében is, történjen az akár közösségi oldalon, akár más weboldalon. A két csoport között nincs különbség az online játékok esetében, viszont ha vásárlásról van szó a Ratkó-korszak szülöttei aktívabbak, és ezzel együtt a veteránok között többen vannak ( $26 \%$ vs. $37 \%$ ), akik még sosem költöttek ilyen módon.
Az innovativitás szerinti csoportokat vizsgálva a nyolc tevékenység közül hat esetében mutatható ki szignifikáns különbség. Ezeket gyakrabban végzik az innovatívabb válaszadók. Amiben nem tér el az egyes csoportok viselkedése, az a közösségi oldalak használata és a hírek olvasása a közösségi oldalakon. Az internetes vásárlásnál látható a legnagyobb különbség aszerint, hogy a megkérdezettek valaha éltek-e már ezzel a lehetőséggel. Míg az

\section{Ha internetezik, milyen gyakran csinálja az alábbiakat? (százalék)}

\begin{tabular}{|c|c|c|c|c|c|}
\hline Generáció & Tevékenység & Soha & Néha & $\begin{array}{c}\text { Gyak- } \\
\text { ran }\end{array}$ & $\begin{array}{l}\text { Nagyon } \\
\text { gyakran }\end{array}$ \\
\hline \multirow{8}{*}{ 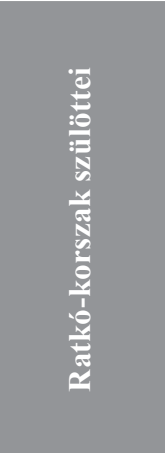 } & E-mailezés & 7,2 & 47,5 & 33,1 & 12,3 \\
\hline & Chatelés (írásos kommunikáció) & 14,8 & 40,5 & 34,5 & 10,2 \\
\hline & Online telefonálás (szóbeli kommunikáció) interneten keresztül & 34,8 & 37,0 & 21,5 & 6,7 \\
\hline & Közösségi oldalak használata & 0,0 & 7,6 & 54,2 & 38,2 \\
\hline & Hírek olvasása közösségi oldalon & 1,7 & 14,5 & 51,0 & 32,8 \\
\hline & Hírek olvasása hírportálon (nem közösségi oldalon) & 4,9 & 24,5 & 39,7 & 30,9 \\
\hline & Internetes játék & 46,5 & 23,9 & 19,3 & 10,2 \\
\hline & Internetes vásárlás & 26,4 & 58,6 & 12,5 & 2,5 \\
\hline \multirow{8}{*}{ 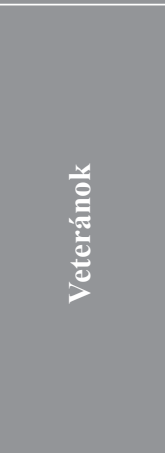 } & E-mailezés & 7,9 & 48,5 & 34,9 & 8,7 \\
\hline & Chatelés (írásos kommunikáció) & 14,6 & 45,0 & 37,1 & 3,3 \\
\hline & Online telefonálás (szóbeli kommunikáció) interneten keresztül & 42,8 & 36,0 & 18,6 & 2,5 \\
\hline & Közösségi oldalak használata & 0,0 & 9,8 & 63,7 & 26,5 \\
\hline & Hírek olvasása közösségi oldalon & 3,3 & 14,3 & 60,0 & 22,4 \\
\hline & Hírek olvasása hírportálon (nem közösségi oldalon) & 5,7 & 32,4 & 43,0 & 18,9 \\
\hline & Internetes játék & 48,3 & 25,8 & 17,1 & 8,8 \\
\hline & Internetes vásárlás & 36,7 & 52,5 & 9,2 & 1,7 \\
\hline
\end{tabular}

Forrás: saját szerkesztés

\section{Milyen gyakran szokott Ön Facebookon...? (százalék)}

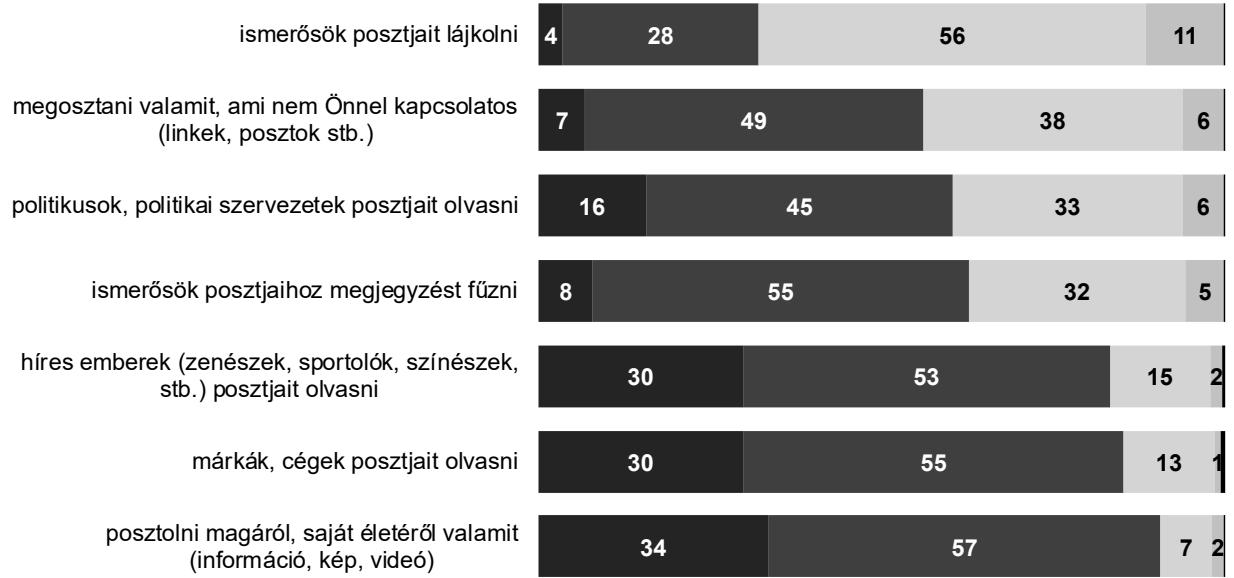


innovátorok és korai adaptálók csoportjában 15 százalék, aki sosem vásárolt még a világhálón, addig a lemaradók esetében 47 százalék ez az arány (a két köztes csoportban, sorban: 22 és $31 \%$ ).

\section{Facebookos tevékenységek}

A facebookos aktivitást hét kérdés segítségével mértük. Ezek eredményei a 6 . ábrán láthatók. A válaszadók egészen kis részére $(8 \%)$ jellemző, hogy ezen tevékenységek valamelyikét sose végezze, ugyanakkor a lájkoláson kívül a legtöbb esetben csak alkalmi gyakoriságról beszélhetünk. Legkevésbé az jellemző a nyugdíjas korosztályra a Facebookon, hogy saját magáról osszon meg valamit. A nőkre valamivel jellemzőbb a lájkolás, mint a férfiakra, ugyanez igaz a márkák, cégek és a híres emberek posztjainak olvasására is. A híres emberek követése jellemzőbb az alacsonyabb iskolai végzettségűekre. A generációk közti különbséget elemezve az látható a 7. táblázatban, hogy a Ratkó-korszak szülöttei gyakrabban, a veteránok ritkábban olvasnak olyan posztokat, amiket cégek, márkák vagy hírességek osztottak meg. Az innovativitás alapján képzett csoportok facebookos szokásai között kevés eltérés figyelhető meg. Az innovatívabb nyugdíjaskorúakra jellemzőbb, hogy megosztanak valamit, akár saját magukról, akár olyan tartalmat, ami nem velük kapcsolatos.

A Facebookon keresztül történő hírfogyasztással kapcsolatban néhány további részletre is rákérdeztünk (7. ábra). Szinte minden válaszadóval (96\%) előfordul, hogy

\section{Milyen gyakran szokott Ön Facebookon ...? (százalék)}

\begin{tabular}{|c|c|c|c|c|c|}
\hline Generáció & Tevékenység & Soha & Néha & $\begin{array}{c}\text { Gyak- } \\
\text { ran }\end{array}$ & $\begin{array}{l}\text { Nagyon } \\
\text { gyakran }\end{array}$ \\
\hline \multirow{7}{*}{ 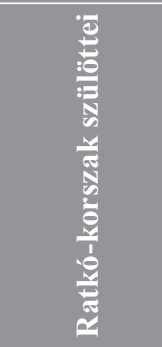 } & posztolni magáról, saját életéről valamit (információ, kép, videó) & 32,6 & 58,8 & 6,7 & 1,9 \\
\hline & megosztani valamit, ami nem Önnel kapcsolatos (linkek, posztok stb.) & 6,5 & 49,3 & 38,0 & 6,1 \\
\hline & ismerősök posztjait lájkolni & 3,5 & 27,4 & 57,7 & 11,4 \\
\hline & ismerősök posztjaihoz megjegyzést füzni & 7,2 & 55,5 & 32,0 & 5,3 \\
\hline & márkák, cégek posztjait olvasni & 28,1 & 56,5 & 14,3 & 1,1 \\
\hline & híres emberek (zenészek, sportolók, színészek stb.) posztjait olvasni & 28,3 & 55,4 & 14,3 & 2,0 \\
\hline & politikusok, politikai szervezetek posztjait olvasni & 15,5 & 45,2 & 33,0 & 6,3 \\
\hline \multirow{7}{*}{ 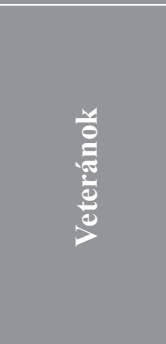 } & posztolni magáról, saját életéről valamit (információ, kép, videó) & 38,3 & 49,8 & 10,3 & 1,6 \\
\hline & megosztani valamit, ami nem Önnel kapcsolatos (linkek, posztok stb.) & 8,6 & 48,8 & 37,7 & 4,9 \\
\hline & ismerősök posztjait lájkolni & 4,5 & 32,8 & 51,6 & 11,1 \\
\hline & ismerősök posztjaihoz megjegyzést füzni & 11,5 & 52,3 & 30,0 & 6,2 \\
\hline & márkák, cégek posztjait olvasni & 38,4 & 52,5 & 9,1 & 0,0 \\
\hline & híres emberek (zenészek, sportolók, színészek stb.) posztjait olvasni & 37,2 & 45,9 & 16,1 & 0,8 \\
\hline & politikusok, politikai szervezetek posztjait olvasni & 17,3 & 42,8 & 35,4 & 4,5 \\
\hline
\end{tabular}

Forrás: saját szerkesztés

\section{Milyen gyakran szokott Ön Facebookon, ha lát egy...? (százalék)}

érdekes megosztott hírt, rákattintani arra a linkre, ahol a hír olvasható

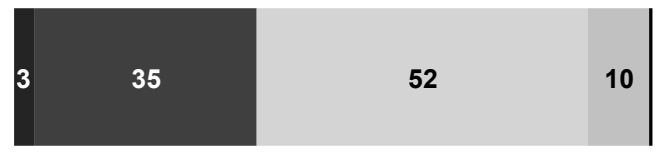

érdekes hírt további információkért keresővel rákeresni
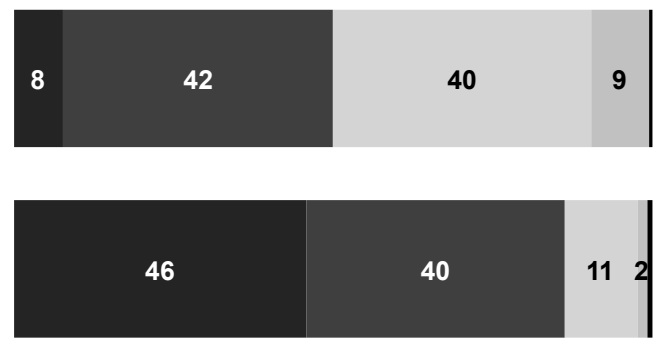

érdekes megosztott hírt, hozzászólni úgy, hogy csak a posztot olvassa el (nem kattint linkre, nem keres rá)
40

9

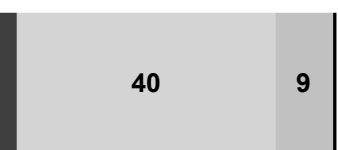

\section{- Soha \\ - Néha \\ Gyakran \\ Nagyon gyakran \\ - Nem tudom/Nem válaszolok}


legalább időnként rákattint egy megosztott hír linkjére, a többség ezt gyakran teszi. Nem sokkal kevesebben (92\%) vannak azok, akik időnként keresőben néznek további információt egy érdekes Facebookon olvasott hírrel kapcsolatban. A válaszadók több mint fele beismerte, hogy elöfordul olyan is, hogy ha látnak egy érdekes megosztott hírt, hozzászólnak úgy, hogy csak a posztot olvassák el, magát a cikket nem.

Ez utóbbi magatartás valamivel jellemzőbb a férfiakra. Ezen kívül a nyugdíjasok egyes csoportjai között kevés eltérés fedezhető fel e kérdésekben. Az innovatívabb válaszadók valamivel gyakrabban kattintanak egy érdekes hír linkjére és jellemzőbb rájuk, hogy más forrásokból is utánanéznek egy-egy információnak.

\section{Facebook-ismerösök}

Kíváncsiak voltunk arra is, hogy a facebookos ismerösök számában is van-e eltérés az egyes válaszadói szegmensek között. Az ismerősök számát nyitott kérdés segítségével mértük. A nagymértékü szórás miatt a mediánok összehasonlítását tekintettük mérvadónak, de az eredményeknél az átlag értékeket is megadtuk. A babyboomereknek (átlag: 363, medián: 200) több ismerősük van a legnagyobb közösségi oldalon, mint a veteránoknak (átlag: 296, medián: 150). Az innovativitás mértékének függvényében kevésbé egyértelmű eredményeket kaptunk, ami megállapítható, hogy a lemaradóknak kevesebb ismerősük van a Facebookon, mint a többieknek (átlag/mediánértékek: innovátorok és korai adaptálók - 391/200, korai többség 407/250, késői többség 343/200, lemaradók 214/120).

\section{Források hitelessége}

Egy kérdéssor segítségével megpróbáltunk arra is rávilágítani, hogy célcsoportunk milyen forrásokat tart hitelesnek. Minden egyes esetben arra kellett válaszolniuk, hogy ha az adott forrásnak általában véve menyire hisznek, a válaszlehetőségek a következők voltak: szinte sose hiszem el, többnyire nem hiszem el, többnyire elhiszem, szinte mindig elhiszem.

Egyes esetekben meglehetősen nagy volt a ,nem tudom/nem válaszolok" választ adók aránya (Youtuberek 23 , rádió $12^{\circ} \%$, újság $11 \%$; többi esetben 4-9\% között), így az eredményeket a releváns választ adókra vetítve értelmeztük. Kevesen válaszolták, hogy mindig hisznek valakinek vagy valaminek. A legmagasabb értéket a Wikipédia esetében mértük, 14 százalék nyilatkozott így, továbbá barátainak a megkérdezettek 9 százaléka hisz minden esetben. A többi forrásnál 0 és 4 százalék közötti eredményt mértünk. Ha a rangsort az alapján állítjuk öszsze, hogy mennyien hisznek mindig és többnyire az egyes forrásoknak, akkor a lista élén a barátok állnak (84\%), ezt követik az ismerösük által Facebookon megosztott tartalmak (65\%), a Wikipédia (60\%), majd általában az interneten látottak, hallottak (49\%). 30 és 39 százalék közötti eredményt mértünk több forrás esetében, ezek: online hírportálokon olvasottak, ismert emberek által Facebookon megosztott tartalmak, tévéhíradóban hallottak, újságban olvasottak, rádióban hallottak. A lista végén a Youtuberek (21\%), a politikusok, politikai szervezetek által Faceboo- kon megosztott tartalmak (17\%), majd a reklámok állnak $(5 \%)$.

A válaszadói csoportok véleményében kevés, illetve nem jelentős különbség mutatkozik. Az viszont megállapítható, hogy általánosságban jellemző, hogy a férfiak kevésbé hisznek az egyes információforrásoknak, mint a nők.

\section{Konklúzió}

Az elméleti bevezetőben érintettük azokat a lényeges tényezőket, amelyekre támaszkodunk a kvantitatív kutatásunkban. A tanulmány aktualitását nemcsak gazdasági szempontok adják, azaz az idősek online vásárlásainak növelési célja, hanem jelentős társadalmi, sőt kulturális előnyök is kapcsolhatók ahhoz, ha a nemzet idős generációja megtanulja kezelni az internetet, legalább felhasználói szinten. A technológia adaptálásának megteremtésével társadalmi problémákat lehet áthidalni, az egészségügygyel kapcsolatos applikációk pedig szinte minden területre pozitív hatást gyakorolhatnak.

A Rogers-féle tipológiákra építve vizsgálhatók az innovációt elutasítók vagy elfogadók belső motivációi. Azonban az idősebb generációnál figyelembe kell venni a kognitív képességeket, hisz az innovációk komplexitása eltérő online felületen, mely akár könnyen károkat is tud okozni. Az általunk vizsgált két generáció életében a relatív előny kevésbé jelenik meg, hisz már eleve idősebbek voltak az internet penetrációjakor (ez mondható el a kompatibilitásról is). Az idősebbek számára az újítások átláthatósága szintén kockázatos, mert biztos ismeret és tudás nélkül nem kísérleteznek online felületekkel. Mindezen korlátokat figyelembe véve az internetes aktivitás időskori hasznossága több szempontból is kimutatható, s így ennek ösztönzése marketingszempontból is jelentős célként fogalmazható meg.

Eredményeink arra mutatnak rá, hogy az internetezö nyugdíjas korosztály körében az internethasználati szokásokban ugyan vannak különbségek a vizsgált generációk között, de az e téren jelentkező eltéréseket sokkal inkább magyarázza a felhasználók innovativitása.

A televízióval, internettel, illetve közösségi oldalakkal töltött időt vizsgálva minimális különbség mutatkozik a Ratkó-korszak szülöttei és a veteránok között. Ha viszont a felhasználók innovativitást vesszük alapul, akkor az látható, hogy az innovatívabb válaszadók többet interneteznek és kevesebb időt töltenek televíziózással, mint kevésbé innovatívabb társaik. Ugyanezt a trendet láthatjuk az egyes generációkon belül is.

Ha azt vizsgáljuk, hogy a megkérdezettek mióta interneteznek, nem látható különbség a két generáció között, mindegyik csoport tagjai átlagosan 15-16 éve léptek elöször a világhálóra. A tekintetben, hogy mit csinálnak az interneten, a két korosztály között már több eltérés látható. A gyakoribb chatelés és online szóbeli kommunikáció jellemző a fiatalabbakra, ugyanígy az intenzívebb közösségimédia-használat és a hírek olvasása akár közösségi oldalon, akár más weboldalon. Ezen túl a Ratkó-korszak szülöttei gyakrabban vásárolnak az interneten, mint a ve- 
teránok. A vizsgált tevékenységek közül az e-mailezés és az internetes játékok használatának gyakoriságában nem különbözik a két csoport.

Az alacsony cellagyakoriságok miatt az innovativitási kategóriákon belül statisztikailag nem igazolhatók a generációs különbségek, de az eloszlások tendenciája arra enged következtetni, hogy e különbségek így is fennállnak. További különbség a Ratkó-korszak szülöttei és a veteránok között, hogy utóbbiak ritkábban olvasnak olyan Facebook posztokat, amiket cégek, márkák, vagy hírességek osztottak meg. Itt megjegyzendő, hogy a politikai tartalmú posztok esetében viszont hasonlóan aktívak. Az idősebb nyugdíjasoknak jellemzően kevesebb ismerősük is van a legnagyobb közösségi oldalon, mint a veteránoknak, viszont ezek ellenére nem töltenek kevesebb időt itt. Mindezek arra engednek következtetni, hogy esetükben e felületen vagy a kevesebb ismerőssel való, de intenzívebb kapcsolattartás jellemzö, vagy pedig a politikai kérdésekben merülnek el mélyebben a Facebookon.

\section{Felhasznált irodalom}

AARP Research (2017). Technology use and Attitudes among Mid-life and Older Americans. Retrieved from https://www.aarp.org/content/dam/aarp/research/ surveys_statistics/technology/info-2018/atom-nov2017-tech-module.doi.10.26419\%252Fres.00210.001. pdf

Adler, R. (2006). Older Americans, Broadband and the Future of the Net. Retrieved from https:/www. seniornet.com

Baker, C., \& McLarty, J. A. (2005). Older Persons and Wireless Telephone Use (Research report). AARP. Retrieved from http://www.aarp.org/research/utilities/ phone/fs116 wireless.html

Antalóczy T., Danó Gy., Kósa É., \& László M. (2017). Digitális Galaxis, 20 év kutatás a médiáról és a gyerekekröl. Budapest: Nemzetközi Gyermekmentő Szolgálat Magyar Egyesület

Baporikar, N. (2014). Innovation in the 21st Century Organization in: Transcultural Marketing for Incremental and Radical Innovation. Hershey: Business Science Reference. https://doi.org/10.4018/978-1-4666-4749-7.ch016

Bokor, A. (2007). Létezik-e itthon Y generáció? Vezetéstudomány, 38(2), 2-21.

Botos, K. (2018). Az elöregedő társadalom problémái. Polgári Szemle, 14(4-6), 95-104. https://doi.org/10.24307/psz.2018.1208

Bőgel Gy. (2008). A schumpeteri „teremtő rombolás” módjai az infokommunikációs iparban. Közgazdasági Szemle, 55(4), 344-360. Retrieved from http://epa.oszk. hu/00000/00017/00147/pdf/04vszbogel.pdf

Cresci, M. K., Yarandi, H. N., \& Morell, R. W. (2010). Pro-nets versus No-nets: differences in urban older adults' predilections for internet use. Educational Gerontology, 36(6), 500-520. https://doi.org/10.1080/03601270903212476

Csizmadia, P. (2017). Everett Rogers innovációs elmélete és annak felhasználási lehetőségei az egészségfejlesztésben. Egészségfejlesztés, 58(4), 5058.

https://doi.org/10.24365/ef.v58i4.208

Dessewffy, T., \& Galácz, A. (2002). Mobilkommunikáció és társadalmi diffúzió. Retrieved from http://www. mta.t-mobile.mpt.bme.hu/dok/3_des.pdf

eNet (2018). Az idősek sem maradhatnak ki a digitális világból! Retrieved from https://enet.hu/hirek/azidosek-sem-maradhatnak-ki-a-digitalis-vilagbol/

Eurostat (2011). Népszámlálási adatbázis, 2011. Retrieved from https://ec.europa.eu/eurostat/web/populationand-housing-census/census-data/2011-census

Eyerman, R., Turner, B.S. (1998). Outline of a Theory of Generations. European Journal of Social Theory, 1(1), 91-106. https://doi.org/10.1177/136843198001001007

Furlong, M. (1995). Cyber Seniors: Technology as a Means, No tan End to Online Community. Digital Media, 5(5), 27-29.

Gergátz, I. (2009). ICT az 50+ generáció életében (Doktori értekezés). Pécsi Tudomány egyetem, Pécs. Retrieved from https://pea.lib.pte.hu/handle/ pea/781?show =full

Grübler, A., Nakicenovic, N., \& Victor, D. G., (1999). Dynamics of Energy Technologies and Global Change. Energy Policy, 27(5), 247-280. https://doi.org/10.1016/s0301-4215(98)00067-6

Holmes, R. (2016). Move Over, Millennials: 5 Things You Need to Know About Generation C. Retrieved from https:/www.inc.com/ryan-holmes/move-overmillennials-5-things-you-need-to-know-aboutgeneration-c.html

Iyer, R., \& Eastman, J. K. (2016). The elderly and their attitudes toward the internet: the impact on the internet use, purchase, and comparison shopping. Journal of Marketing Theory and Practice, 14(1), 56-67. https://doi.org/10.2753/mtp1069-6679140104

Izal, A. (2002). The older or ageing consumers in the UK: are they really that different? International Journal of Market Research, 44(3), 337-359. https://doi.org/10.1177/147078530204400305

Kanayama, T. (2003). Ethnographic Research on the Experience of Japanese Elderly People Online. New Media and Society, 5(2), 267-288. https://doi.org/10.1177/1461444803005002007

Kapitány, B. (2015). Demográfiai fogalomtár: KSH Népességtudományi Kutatóintézet. Retrieved from https://www.demografia.hu/hu/letoltes/fogalomtar/ pdf/varhato-atlagos-elettartam.pdf

Kennett, P. A., Moschis, P. G., \& Bellenger, D. N. (1995). Marketing financial services to mature consumers. Journal of Services Marketing, 9(2), 62-72. https://doi.org/10.1108/08876049510086026

KSH (2017). Távközlés, televizió- és internetszolgáltatás - IKT-eszközök és használatuk a háztartásokban, a vállalkozásoknál és a közigazgatásban. Retrieved from https://www.ksh.hu/docs/hun/xftp/idoszaki/ikt/ ikt17.pdf 
Kolos, K. (2014). Az ötvenen túli fogyasztók vizsgálata a szolgáltató szektorban (Doktori disszertáció). Budapesti Corvinus Egyetem, Budapest.

Kovács, G., Aczél, P., \& Bokor, T. (2018). Magyar egyetemisták vélekedései az idősekről. Kommunikáció, Közvélemény, Média, 2018(3), 62-93. http://doi.org/10.20520/jel-kep.2018.3.63

Laukkanen, T., Sinkkonen, S., Kivijarvi, M., \& Laukkanen, P. (2007). Innovation resistance among mature consumers. Journal of Consumer Marketing, 24(7), 419-427. https://doi.org/10.1108/07363760710834834

Lee, Ch., \& Coughlin, J.F. (2015). Older adults' adoption of technology: an integrated approach to identifying determinants and barriers. Journal of Product Innovation Marketing, 32(5), 747-759. https://oi.org/10.1111/jpim.12176

Linden, F. (1986). Spending boom and bust. American Demographics, October, p. 25.

Lumpkin, J.R., Greenberg, B.A., \& Goldstucker, J.L. (1985). Marketing place needs of the elderly: determinant attributes and store choice. Journal of Retailing, 61(2), 75-105. https://doi.org/10.1177/095148489600900203

Mannheim, K. (1928). Essays on the Sociology of Knowledge. Oxford: Oxford University Press.

Moschis, G., Curasi, C., \& Bellenger, D. (2004). Patronage motives of mature consumers in the selection of food and grocery stores. Journal of Consumer Marketing, 21(2), 123-133. https://doi.org/10.1108/07363760410525687

Niehaves, B., \& Plattfaut, R. (2014). Internet adoption by elderly: employing IS technology acceptance theories for understanding the age-related digital divide. European Journal of Information Systems, 23(6), 708726. https://doi.org/10.1057/ejis.2013.19

Nielsen (2018). Közönségmérés: Havi statisztikák. 2018. február. Retrieved from http://www.nielsentam.tv/ Uploads/Hungary/Honlap_havi_statist_201802.pdf

Ogozalek, V.Z. (1991). The Social Impacts of Computing: Computer Technology and the Graying of America. Social Science Computer Review, 9(4), 655-656. https://doi.org/10.1177/089443939100900409

Pew Research Center (2018). Millennials stand out for their technology use, but older generations also embrace digital life. Retrieved from https://www.pewresearch. org/fact-tank/2018/05/02/millennials-stand-out-for- their-technology-use-but-older-generations-alsoembrace-digital-life/

Proctor, B. D., Semega, J. L., \& Kollar, M. A. (2016). Income and Poverty in the United States: 2015. United States Census Bureau. Retrieved from https://www.census. gov/content/dam/Census/library/publications/2016/ demo/p60-256.pdf

Rogers, E.(1995). Diffusion of Innovations. New York: The Free Press.

Schumpeter, A.J. (1980). A gazdasági fejlödés elmélete. Budapest: Közgazdasági és Jogi Könyvkiadó.

Shukla, A. (2009). What is Innovation? Why Innovation Is Important? Retrieved from http://www.paggu. com/getting-into-roots/what-is-innovation-whyinnovation-is-important/

Székelyi, M., \& Barna, I. (2004). Túlélőkészlet az SPSShez. Budapest: Typotex Kiadó.

Tari, A. (2014). Z generáció. Budapest: Jaffa Kiadó.

Termekmix.hu (2018). Gyerekcipőben járó szeniormarketing. Retrieved from http://termekmix. $\mathrm{hu} / \mathrm{magazin} / \mathrm{marketing} / 416$-gyerekcipoben-jaroszeniormarketing

Törőcsik, M. (2009). Generációs marketing. In Bugár Gy. \& Farkas F. (eds.), Elkötelezettség és sokoldalúság. Tanulmánykötet Barakonyi Károly tiszteletére (pp. 221-228). Pécs: Pécsi Tudományegyetem Közgazdaságtudományi Kar.

Töröcsik, M. (2019). Generációs kutatás. http://drtorocsik.hu/generacios.html 2019. 05. 05.

Törőcsik, M., \& Lampek, K. (2016). Lázadó generáció új élethelyzetben... értékrendek és gyökereik 50 év felett. Magyar Fogyasztó, 2(3), 12-22. Retrieved from https:// issuu.com/braunandpartners/docs/mfp_50

Törőcsik, M., \& Németh, P. (2018). Ageing. A magyar lakosság korral, öregedéssel kapcsolatos beállítódása generációs szemléletü vizsgálattal (Kézirat). EFOP3.6.1-16-2016-00004. Pécs: PTE KTK. Retrieved from https://ktk.pte.hu/sites/ktk.pte.hu/files/images/ tudomany/rendezvenyek/fogyasztas/efop_ generaciok_alaptanulmany_ageing_2018_jav.pdf.

White, H., McConell, E., Clipp E., Bynum L., Teague C., Navas L., Craven S., \& Halbrecht, H. (1999). Surfing the Net in Later Life: a Review of the Literature and Pilot Study of Computer Use and Quality of Life. Journal of Applied Gerontology, 18(3), 358-378. https:// doi.org/10.1177/073346489901800306

Yankelovich monitor: elérhető a hivatalos weboldalon: http://www.yankelovich.com 